\title{
PERSEPSI DAN TINGKAT PARTISIPASI SUKU BAJO TERHADAP PEDIDIKAN ISLAM
}

\author{
The Perception and Participation \\ Level of Bajo Tribe to Islamic Education
}

\author{
Abdullah K \\ Sekolah Tinggi Agama Islam Negeri Watampone \\ Jl. Andi Maddepungeng BTN Timurama I B6/01 Watampone, Fax: 048123754 \\ Email: AbdullahKatutu@yahoo.co.id
}

Naskah diterima tanggal 15 Maret 2014. Naskah direvisi tanggal 15 April 2014. Naskah disetujui tanggal 2 Mei 2014

\begin{abstract}
Abstrak
Tujuan penelitian: 1) mendapatkan gambaran yang tepat mengenai pola dan orientasi hidup Suku Bajo; 2) mengungkapkan persepsi Suku Bajo tentang pendidikan Islam. 3) memahami tingkat partisipasi Suku Bajo terhadap pendidikan Islam. Dari penelitian ditemukan bahwa: 1) Pola hidup berorientasi laut pada Suku Bajo, karena laut dijadikan sebagai lumbung makanan, obat, lalu lintas, tempat menguatkan badan, tempat tinggal, sahabat dan tempat bersemayam roh nenek moyangnya. 2) Kemudian persepsi orang tua Bajo tentang pendidikan Islam masih sangat negatif, lemah, belum diminati dan belum dibutuhkan, karena ilmu yang dibutuhkan adalah ilmu mencari ikan, ilmu itu telah diwarisi dari leluhurnya dan tidak mempunyai waktu untuk bersekolah di darat. 3)Tingkat partisipasi Suku Bajo terhadap pendidikan masih sangat rendah karena sepanjang waktu beraktivitas di laut.
\end{abstract}

Kata kunci: pola hidup, persepsi, partisipasi, Suku Bajo, pendidikan Islam

\begin{abstract}
This qualitative study aimed at identifying; 1) the pattern and the orientation of the tribe Bajos life; 2) The perception of Bajo people toward Islamic religious education, and 3) The participation of Bajo tribe in the Islamic religious education. The techniques of collecting data were interviews, and direct observations. The results show that the lifestyles of Bajo people were entirely oriented to sea. Sea fulfills spiritual, social, and logistical to the Bajo people. The abundant see becomes the main source of their life. Bajo community stated that Islamic education is not important to their lives because it was considered not sufficient to meet their needs for education. For them, the needed knowledge is about see such as fishing knowledge. As a result, their participation in education is minimum. Very few children of Bajo attended school.
\end{abstract}

Keywords: lifestyle, perception, participation, Bajo tribe, islamic education

\section{PENDAHULUAN}

S uku Bajo di Kabupaten Bone sebanyak 250 KK dengan penduduk sebanyak 1275 jiwa, 625 laki-laki dan 650 perempuan yang mendiami perkampungan Suku Bajo seluas dua hektoare, sehingga nampak rumah mereka sangat berdekatan antara satu dengan lainnya, karena selalu memberikan peluang kepada generasinya untuk membangun rumah di selah-selah rumah mereka.

Suku Bajo di Kabupaten Bone memiliki keunikan karena hanya berfokus mencari rezeki di laut saja dengan tumpuan mendapatkan ikan atau hasil laut lainnya dalam rangka memenuhi kebutuhannya.

Nama Suku Bajo diberikan oleh orang Bugis, asal katanya tabbajao-bajo mengandung arti terbayang-bayang pada sore hari dari kejauhan 
di pantai Teluk Bone, orang Sumatera memberi gelar suku Bajo sebagai orang yang suka merantau, sementara orang Lamaholot menggelarnya sebagai orang yang kerjanya mendayung perahu dan ada juga yang menggelarnya suku terasing. Suku Bajo mempunyai, adat, tradisi, strata sosial dan bahasa sendiri yang disebut bahasa Bajo atau bahasa Sama (Samal). Suku Bajo menolak cara hidup di darat karena tidak punya pengetahuan dan pegalaman seperti bertani, berkebun, dan berternak dengan alasan psikologis, ekonomis, keterampilan, dan mitos kepercayaan dari nenek moyang mereka. Kalau di darat mereka harus menunggu hasil usahanya dalam waktu yang cukup lama, mereka tidak dapat bersabar dan lebih betah di laut, karena usahanya hari ini dapat dinikmati hasilnya pada hari ini juga. Secara mitos Suku Bajo merasa terlanjur ditakdirkan oleh Allah swt. Berorientasi hidup di laut, yang telah diwarisi dari nenek moyangnya, sebagaimana Allah telah menakdirkan suku lain yang orientasi hidupnya di darat. Pola dan orientasi hidup di laut itulah yang menjadi perhatian penulis untuk melihat persepsi dan partisipasinya terhadap pendidikan Islam yang tempatnya di darat.

\section{METODE PENELITIAN}

Operasionalisasi penelitian ini menggunakan pendekatan kualitatif sebagai pedoman metodologi. Lokasi penelitian: Kelurahan Bajoe Kecamatan Tanete Riattang Timur Kabupaten Bone. Instrumen utama dalam penelitian ini adalah peneliti sendiri, yang dalam upaya memperoleh data empiris, menggunakan seperangkat instrumen dalam bentuk pedoman interviu, catatan lapangan dengan sasaran penelitian adalah anak-anak, orang tua dan Lolo Bajo, perangkat kelurahan, tokoh masyarakat, para pembina/madrasah dan sekolah. Dalam menyelesaikan masalah digunakan pendekatan edukatif dan psikologis dengan sentuhan: teologis deskriptif, filosofis, sosiologis, antropologis, dan historis. Selanjutnya, data diolah dan dianalisis secara deskriptif setelah dilakukan trianggulasi.

\section{HASIL PENELITIAN}

Gambaran Pola dan Orientasi Hidup di Laut bagi Suku Bajo di Kabupaten Bone Pola Hidup Suku Bajo di Bone

Suku Bajo merupakan orang Indonesia yang dianggap paling mengenal laut dan kehidupan di dalamnya. Pengetahuan, kemampuan dan keakraban Suku Bajo terhadap laut yang begitu kompleks tampaknya tidak tertandingi oleh suku lain, sehingga menjadilah Suku Bajo sebagai suku yang superior dalam budaya lautnya dan lebih jago dari masyarakat di darat dalam melaut.

Suku Bajo memandang bahwa laut adalah milik bersama, oleh karena itu tidak dikenal adanya pengkaplingan seperti perkampungan di darat, sehingga Suku Bajo memanfaatkan daerah perairan di sekitarnya bahkan sampai menjangkau daerah lain (Kabupaten dan Provinsi lain) sesuai kemampuan pembekalan dan peralatan yang mereka persiapkan.

Kelurahan Bajoe menjadi tempat satusatunya sebagai pemukiman permanen.Suku Bajo di Kabupaten Bone. Dalam melaksanakan aktivitas sebagai nelayan. Suku Bajo menggunakan perahu sebagai alat utama dalam kegiatan penangkapan ikan. Untuk menggerakkan perahu digunakan dayung dan layar. Di mata Suku Bajo laut adalah satu-satunya sumber penghidupan. Mereka tidak dapat dipisahkan dengan perahu. Mereka tidak pernah lepas dari laut, karena di laut tersimpan perbendaharaan dan kekayaan yang tidak ada habisnya.

Bagi Suku Bajo Laut adalah lumbung makanan, obat, lalu lintas, menguatkan badan, tempat tinggal, sahabat, tempat bersemayamnya roh leluhur. Suku Bajo menjadi salah satu ethnic di Indonesia yang memiliki kebudayaan bahari (aqua culture), atau hidup menurut tata kehidupan kemaritiman yang populasinya cukup besar dan menyebar ke seluruh Nusantara, ada yang masih tinggal diperahu, di tepi pantai dan di pemukiman (Laode Muharram, 1993: 23).

Pemukiman Suku Bajo selalu mengarah ke laut dan rumah mereka dibangun di atas air menghadap ke laut.. Hal tersebut menurut Rustan Talibbe Kepala Kelurahan Bajoe mengandung aspek filosofis dan psikologis yang tidak dapat diabaikan begitu saja karena: air laut sebagai pedoman untuk menetapkan saat yang tepat untuk turun ke laut, yaitu ketika terdengarnya desiran ombak pada saat air pasang (lakale-ale goyak); air laut sebagai penenteram hati, penghibur dan pengantar tidur di waktu istirahat karena pengaruh gelombang pasang membuat perahu (bidok) terolang-oleng (palelenge) disebabkan buaian ombak yang menghempas di lambung perahu, seolah-olah menjadi nada dan irama perpisahan untuk sementara; di atas air laut akan mempercepat dan mempermudah para nelayan untuk bertolak ke laut sewaktu air pasang karena bidok sedang terapung siap meluncur ke laut (wawancara, 7/1/2013). 
Kecintaan Suku Bajo terhadap laut terjadi ratusan tahun yang lalu, diduga bermula ketika mereka menghindari peperangan dan kericuhan di darat atau masa paceklik yang berkepanjangan, lalu kemudian Suku Bajo merasakan kedamaian hidup di laut, walaupun untuk pertama kalinya hanya hidup di atas perahu yang diberi atap (Dahlan Sawe, 1985:43).

Pola hidup Suku Bajo dimaknai dengan kerja keras dengan penuh kehati-hatian, sederhana dan partisipatif. Gelar pelaut ulung yang ditujukan bagi Suku Bajo, bukan suatu gelar rekayasa, tetapi mereka melakukan kegiatannya dengan hati-hati dan penuh kesungguhan dan pertimbangan, mengingat laut adalah medan yang sarat dengan berbagai rintangan dan bahaya yang sewaktu-waktu datang mengancam keselamatan. Suku Bajo dalam melaut menggunakan alat sederhana seperti pukat, pancing, jala, tombak dan bubu, sehingga dengan cara itu mampu mendapatkan ikan sekedar memenuhi keperluan sehari-hari. Terkait dengan aktivitas Suku Bajo A. Edy Masserang Seksi Pemberdayaan Masyarakat Kelurahan Bajoe, mengatakan bahwa "Suku Bajo hanya bergiat dan beraktivitas dibidang kelautan saja, karena sampai hari ini belum ada Suku Bajo yang kerja di empang, menjadi Guru, PNS, tentara, polisi, securiti, buruh pelabuhan dan wirausaha di luar hasil laut" (wawancara, 8/1/2013).

Suku Bajo merasa bangga dan nikmat menjadi Suku Bajo dengan cara hidup sederhana, mereka tidak berkeluh kesah dan tidak putus asa menghadapi hidup walaupun dengan penghasilan hanya sekedar memenuhi kebutuhan konsumsi sehari-hari.

Sejak kecil anak laki-laki mereka sudah mulai dilibatkan ikut mencari rezeki di tengah keganasan ombak samudera. Tolong-menolong menjadi bagian dari kehidupannya, sehingga orang tua Bajo yang belum punya perahu, rumah dan alat penangkap ikan akan dipinjamkan oleh sesamanya, begitu juga kalau belum mendapatkan hasil tangkapan akan disumbangkan dari teman sesama sekedar untuk memenuhi kebutuhan konsumsi hari itu. Suku Bajo sebagai pengelana laut selalu berpartisipasi terhadap pemerintah setempat, seperti membayar pajak dan menjadi benteng pertahanan kerajaan Bone di sisi laut Teluk Bone (Herman Soesangobing, 1977: 18).

\section{Orientasi Hidup Suku Bajo di Bone}

Suku Bajo di Kabupaten Bone dalam orientasi hidup mencari rezeki di laut terbagi dalam empat kelompok yaitu: a. Pallibu adalah kelompok nelayan yang beraktivitas selama satu atau dua hari dengan menggunakan perahu lepa-lepa yang didayung. Setelah mendapatkan ikan, kelompok nelayan ini kembali ke darat untuk menjual hasil tangkapannya yang sebagiannya untuk dikonsumsi bersama keluarga.b. Papongka adalah kelompok nelayan yang berada di laut selama seminggu atau dua minggu dengan menggunakan perahu sope. Setelah memperoleh hasil mereka kembali ke darat. Tetapi kalau tempat mencari ikan agak jauh, maka hasilnya dijual kepada masyarakat yang tinggal di pulau-pulau terdekat sambil membenahi kebutuhan perbekalan terutama persiapan air minum untuk kembali lagi mencari ikan, sehingga tidak selalu membawa pulang hasil tangkapannya dalam bentuk ikan yang banyak, tetapi dalam bentuk uang karena telah dijual pada masyarakat di pulau-pulau terdekat. c. Sakai adalah kelompok nelayan yang menggunakan waktu yang agak lama yaitu satu hingga dua bulan, karena wilayah pencarian ikan lebih luas yang terkadang menembus antar provinsi atau antar pulau yang secara praktis menggunakan perahu besar bermesin. $d$. Lame adalah kelompok nelayan berkelas yang menggunakan waktu yang cukup lama yaitu tiga hingga beberapa bulan dengan menggunakan perahu besar atau sejenis kapal, sehingga secara otomatis mempersiapkan bekal yang lebih besar dan awak kapal yang memadai sesuai kebutuhan dan kepentingan perjalanan dan pencarian ikan. (wawancara dengan Roso, 9/1/2013).

Kelompok pencari ikan tersebut beroperasi sepanjang waktu silih berganti sesuai dengan kondisi yang ada dan tinggal memilih jenis kelompok mana yang akan dijalankan sesuai dengan persiapan dan peralatan yang ada.

Orientasi hidup di laut bagi Suku Bajo dapat tergambar dalam hal kepiawaian melaut dan mencari ikan, dijelaskan oleh $\mathrm{H}$. Lolo Tokoh masyarakat Kelurahan Bajoe, bahwa dengan melihat ikan kecil berenang sambil bermain di sekitar gugusan karang merupakan pertanda bagi Suku Bajo bahwa di tempat itu banyak ikan. Cara untuk menangkapnya harus menghadang arus karena ikan selalu mengikuti arus. Kemudian, waktu yang tepat menurut pandangan Suku Bajo adalah pada pagi dan sore hari, ketika air laut tidak begitu panas atau bulan lagi redup, karena pada saat seperti itu ikan senang bermain di permukaan air, sehingga lebih mudah ditangkap. Sebaliknya, jika udara panas dan bulan purnama maka ikan-ikan turun ke dasar laut 
sekitar dua puluh meter dari permukaan air. Bila orang Bajo sementara berlayar lalu melihat laut tidak berombak, tidak berarus keras, banyak buih terapung, berdesir dan bau anyir maka dipastikan bahwa di tempat itu ada karang. untuk menebak karang itu hanya memeriksa biji pelirnya, kalau biji pelirnya mengecil di sebelah kiri, maka menjadi pertanda karang itu berada di sebelah kiri begitu pula sebaliknya jika biji pelirnya mengecil di sebelah kanan maka menjadi pertanda karang itu berada di sebelah kanan. (wawancara, 14/1/2013).

Sejalan dengan pernyataann Anwar Hafidz sejarawan Universitas Haluoleo (Unhalu) di Kendari mengatakan bahwa begitu dalam pengenalan Suku Bajo terhadap kehidupan di laut, sehingga memiliki kemampuan mendiagnosis penyakit ikan tertentu di laut. Demikian pula pengetahuan mereka tentang gejala alam yang memberi pertanda tentang ada atau tidaknya konsentrasi ikan di suatu tempat di tengah laut (Sudirman Saad, 2009: 60).

Pencarian ikan dilakukan secara berkelompok. Orientasi penangkapan ikan, pencarian tiram dan akar bahar pada suku Bajo dilakoni secara kelompok yang kecil (ayah dan anak). Kemudian cara sederhana itu berkembang dengan meniru atau magang dari Suku Bugis, karena Suku Bugis mempunyai keragaman pencarian sebagai nelayan (pakkaja): 1) Pallambik (menggunakan jaring atau pukat) yang waktunya seminggu dengan jumlah anggota antara 5-10 orang. 2) Pattabere menggunakan kail atau pancing dalam jumlah ratusan, beranggotakan 4-5 orang, waktu yang digunakan kisaran seminggu, yang pada umumnya kembali sebelum jumatan agar tidak absen dalam salat Jum'at. 3) Paccampau menggunakan pancing dan ikut bersama pattabere ke area lokasi pencarian ikan, tetapi tidak terikat dengan pembagian hasil, karena tidak permanen dan temporer. Paccampau lebih bersifat rekreasi atau kunjungan khusus untuk ikut bersama ke laut dari sahabat atau keluarga. 4) Pappanah, panombak, dan pallinta (memanah, menombak dan memancing) memusatkan perhatiannya pada pencarian taripang, cumi-cumi, samampara, ikan kecil, gurita, siput, tiram dan akar bahar. (wawancara dengan H. Mudding, 8/3/2013).

Penyebaran Suku Bajo dalam mencari ikan meliputi semua kelompokyang sewaktu-waktu dapat bergeser ke kelompok lainnya sesuai kepentingan pencarian ikan di laut. Nelayan pappanah dan sejenisnya menggunakan perahu dayung (lepalepa), pallambik menggunakan perahu motor yang disebut bodi-bodi, sedangkan nelayan pattabbere menggunakan perahu motor yang disebut jarangka.

Jenis ikan yang sering menjadi hasil tangkapan Suku Bajo: ikan layang, tembang, tongkol, cakalang, tenggiri, julung, cangkulungan, bawal, kembung, barucuda, kerapu, kakap, teri, balanak, tuna, gurita, kepiting, udang dan lainnya. Ikan cakalang dan tuna menjadi andalan para nelayan karena dihasilkan sepanjang tahun dan dapat diperoleh setiap hari.

Pada umumnya nelayan membedakan musim barat yang biasanya berlangsung bulan Nopember hingga Pebruari dengan musim timur yang biasanya berlangsung dari bulan Mei hingga Agustus. Selama musim barat angin bertiup kencang dan bergelombang besar, sehingga nelayan tradisional enggan melaut yang berarti musim barat adalah musim paceklik. Pada musim angin barat para nelayan berkesempatan memperbaiki peralatannya sambil menunggu berakhirnya musim barat (Lihat Loekman Sutrisno Mubyarto dan Michael Dove, 1984: 11).

b) Pencarian ikan di laut cenderung berpindahpindah. Kehidupan suku Bajo sebagai

seanomaden, ternyata tidak pernah merasa kecewa dan berkecil hati dalam menghadapi tantangan hidup dan kehidupan, walaupun hasil tangkapannya hanya dapat memenuhi kebutuhan pangan. Laut menjadi lumbung kesejahteraan Suku Bajo di Kabupaten Bone, karena sepanjang Teluk Bone dan pulau-pulau sekitar lainnya menjadi wilayah yang subur dan indah khususnya bagi Suku Bajo dengan mencari rezeki secara berpindahpindah pada tempat yang dianggap strategi dan aman.

\section{Persepsi Suku Bajo tentang Pendidikan Islam}

Orang tua Bajo punya persepsi tersendiri tentang belajar dan pendidikan, sehingga dengan persepsinya itu mewarnai corak berpikirnya dan pola perilakunya, baik terhadap sukunya maupun terhadap pendidikan anak-anaknya. Persepsi orang tua Bajo tergambar dalam sikap, motivasi, minat, pengetahuan dan pengalamannya, kepentingan dan harapannya yang dikaitkan dengan belajar ataupun persekolahan sesuai latar belakangnya sebagai etnik group yang berorientasi hidup di laut.

\section{Persepsi Suku Bajo dalam bentuk sikap terhadap pendidikan Islam}

Keadaan pendidikan Suku Bajo jauh ketinggalan dibanding dengan Suku Bugis. Secara umum masih memperlihatkan kondisi 
ekonomi lemah dan mempunyai kecenderungan menutup diri dari lingkungan sosialnya, serta tidak proaktif dalam menghadapi perkembangan dan perubahan zaman. Pada umumnya orang tua Bajo menunjukkan sikap rendah diri dan cepat merasa puas dengan pekerjaannya sebagai nelayan, dan sepertinya merasa tidak punya masalah, walaupun menurut suku lain dianggap mengalami dan memiliki segudang masalah. Perasaan yang demikian menjadi jimat bagi Suku Bajo untuk tetap tegar dan mampu bertahan lama dalam menghadapi kompleksitas kesulitan kehidupan dan tantangan kemajuan zaman.

Suku Bajo tidak pernah membayangkan bahwa dirinya dan anak-anaknya dapat diangkat dan duduk di lembaga eksekutif, yudikatif maupun di legislatif, karena selama ini tidak pernah ada seperti itu, sehingga sikap mereka menganggap bahwa pendidikan bukan untuk orang Bajo yang berorientasi hidup di laut, karena jabatan seperti itu tidak ada di laut.

Suku Bajo berpandangan bahwa sekolah dengan aktivitas belajar secara disiplin dan ketat hanya akan membuat anak-anak Suku Bajo menderita karena mereka merasa dikungkung dan tidak diberi kebebasan, sehingga anak-anak Suku Bajo pada umumnya cenderung bersikap pembolos pada jam pelajaran pada waktu tertentu yaitu di saat orang tuanya tiba dari mencari ikan. Hal itu terjadi karena terbawa arus kebiasaan bagi anak-anak Suku Bajo selalu ikut serta membantu orang tuanya menurunkan hasil tangkapan sambil bermain di air.

Orang tua suku Bajo belum menampilkan sikap yang positif terhadap sekolah dan belajar, baik dengan alasan kebebasan yang tidak mau diganggu dengan kegiatan belajar, maupun dengan alasan karena selalu mengikutkan anak-anaknya khususnya usia pendidikan dasar untuk mencari rezeki di laut. Terkait persepsi Suku Bajo dalam bentuk sikap, A. Herlina (Seksi Perekonomian \& Kesejahteraan Kelurahan Bajoe) mengemukakan bahwa: Pemuda Suku Bajo pada umumnya kurang sekali yang studi lanjut, karena begitu tahu membaca, menulis dan menghitung mereka cenderung berhenti sekolah, sehingga kebanyakan tidak tamat di MIS dan terjung membantu orang tua mencari rezeki di laut, sebagian pergi merantau ke daerah dan negara lain dengan tetap melakoni pencarian rezeki di laut (wawancara, 8/1/2013).

Pada umumnya Suku Bajo memiliki sikap mental dan sikap hidup yang dipengaruhi oleh kebiasaan melaut dan juga relatif rendahnya tingkat pendidikan, sehingga menghambat masuknya pola pikir yang dinamis, termasuk penyerapan teknologi berjalan lambat. Selain itu keterampilan yang rendah pada masyarakat Suku Bajo menyebabkan tenaga kerja yang ada lebih merupakan beban pembangunan daripada sebagai aktor sosial yang produktif, yang pada akhirnya terjadi ketimpangan sosial ekonomi (Muhammad Yamin, 1996: 23). Dengan demikian sikap tertutup orang tua Suku Bajo menjadi faktor penghambat dalam meningkatkan taraf pendidikan anak-anaknya.

\section{Persepsi Suku Bajo dalam bentuk motivasi terhadap pendidikan Islam}

Orang tua Bajo tergolong akrab dan sayang terhadap anaknya, tidak kasar dn tidak fatal apalagi marah secara serampangan. Meskipun demikian, mereka juga tidak pernah memberi hadiah dan sangat terbatas dalam memberikan pujian, bahkan pada umumnya mereka tidak memperhatikan persekolahan bagi anak-anaknya. Orang tua Bajo tidak pernah stres dalam menghadapi anak-anaknya, karena tidak pernah serius memerintahkan sesuatu dalam menggiring anak-anaknya untuk belajar atau bersekolah, belum tumbuh motivasi dan kesadarannya terhadap pendidikan, baik pendidikan umum maupun pendidikan Islam. Orang tua Bajo belum punya pengharapan dari belajar. sehingga sampai dewasa ini belum ditemukan adanya orang tua suku Bajo yang menyiapkan ruang belajar khusus bagi anak-anaknya, apalagi yang namanya alat-alat dan pembimbingan, karena pada umumnya masih miskin dan mereka belum pernah sekolah.

Sikaphiduporangtuayanglebihmementingkan mencari rezeki di laut sepanjang hari dan sepanjang tahun sangat berdampak secara negatif terhadap anak-anaknya dalam menghadapi aktivitas belajar dan cenderung terjadi krisis motivasi dan belum memiliki achievement motivation, dalam pendidikan dari generasi ke generasi. Dengan demikian nampak bahwa motivasi hidup nelayan suku Bajo di Bone lebih terfokus pada kebutuhan fisiologis dan kebutuhan rasa aman, sedangkan kebutuhan sosial, berprestasi dan aktualisasi diri belum mendapatkan perhatian. Walaupun demikian, motivasi nilai-nilai agama Islam mulai mendapatkan perhatian, apalagi setelah dibangunkan mesjid yang cukup besar dan megah di tengah-tengah pemukiman suku Bajo. Nelayan Suku Bajo seperti tabu turun di laut pada hari Jumat, bahkan pada sore hari Kamis pada umumnya pulang ke darat agar tidak alpa pada 
salat Jumat, dan beberapa orang di antaranya telah menunaikan ibadah haji.

\section{Persepsi Suku Bajo dalam bentuk minat terhadap pendidikan Islam}

Menurut minat orang tua suku Bajo, pengetahuan yang penting adalah pengetahuan untuk menangkap ikan, sedang pengetahuan tersebut pada dasarnya telah diwarisi secara turun-temurun, sehingga tidak perlu sekolah lagi. belajar di sekolah hanya menghabiskan waktu dan mengurangi kesempatan dalam mencari rezeki di laut. Anggapan seperti itu menjadikan lemahnya perhatian terhadap pendidikan pada umumnya dan pendidikan Islam pada khususnya karena Suku Bajo belum menjadikan ilmu sebagai obor atau cahaya yang mampu memberikan petunjuk dalam meraih kebahagiaan, baik di dunia maupun di akhirat.

\section{Persepsi Suku Bajo dalam bentuk pengetahuan dan pengalaman terhadap pendidikan Islam}

Pengetahuan dan pengalaman Suku Bajo mengenai agama dan pendidikan Islam sangatlah minim karena hanya berpindah dari suatu pesisir ke pesisir lainnya, sehingga tidak punya idealisme tentang pendidikan, namun pengetahuan dan pengalaman Suku Bajo mengenai kondisi, sifat serta kandungan makna terhadap perairan seperti: astronomi, iklim, cuaca, teknik pembuatan perahu, teknik pembuatan dan perawatan alat penangkap ikan menjadi totalitas dari sistem pengetahuan mereka. Pengetahuan dan pengalaman Suku Bajo diperoleh melalui warisan yang turun-temurun. Selain itu, praktek hidup sehari-hari menjadi dasar dalam mempersepsi tentang pendidikan Islam. Pengetahuan yang dibutuhkan adalah yang terkait dengan kepentingan mencari ikan dan hasil laut lainnya.

Tentu masih banyak spesifikasi ilmu pengetahuan yang sangat dibutuhkan Suku Bajo, baik yang terkait langsung dengan pendidikan Islam (aqidah, ibadah dan akhlak), maupun yang terkait dengan mata pencahariannya seperti cara melestarikan terumbu karang, membudi dayakan ikan, mengawetkan ikan hasil tangkapan agar tidak cepat rusak, mencari jaringan pemasaran yang lebih menguntungkan dan sebagainya, tetapi semuanya itu tidak dapat dilakukan, karena tempat orang bersekolah untuk menimba ilmu pengetahuan secara khusus berada di darat yang jauh dari perkampungan Suku Bajo.

\section{Persepsi Suku Bajo dalam bentuk kepentingan dan harapan (aspirasi) terhadap pendidikan Islam}

Suku Bajo menganggap bahwa belajar itu tidak perlu karena kedudukan dan kekayaan bukan untuk suku Bajo tetapi adalah untuk suku lain. Hal yang perlu bagi suku Bajo adalah mencari ikan karena hal itu menyangkut kebutuhan pribadi dan keluarga. Orang tua Bajo memandang bahwa kelahiran anak di tengah-tengah keluarga merupakan karunia tuhan yang tak ternilai harganya karena di samping sebagai pelanjut turunan dan penyambung citacita, juga mempunyai nilai ekonomis bagi orang tua karena dapat membantu orang tua mencari nafkah setelah besar. Orang tua Bajo belum mampu memahami dan menghayati bagaimana pentingnya iptek dan imtaq, karena dikalangan mereka belum ada orang ilmuwan, belum punya ustaz dan kiai yang senantiasa memberikan wejangan dan nasehat yang patut diikuti sepak terjangnya.

\section{Tingkat Partisipasi Suku terhadap Pendidikan Islam}

Tingkat partisipasi Suku bajo terhadap pendidikan Islam melalui tri pusat pendidikan yaitu: pendidikan informal, pendidikan formal dan pendidikan non-formal.

\section{Partisipasi Suku Bajo di Kabupaten Bone secara Formal terhadap Pendidikan Islam}

Pada dasarnya pelaksanaan pendidikan Islam pada Suku Bajo secara informal, dilakukan di rumah dan di perahu. Orang tua Bajo dalam mendidik anak-anaknya dengan berbagai pengalaman melaut dilaksanakan di rumah dan diperahu oleh sang ayah, sebagaimana dikemukakan oleh Buba dari Suku Bajo bahwa anak usia tiga hingga enam tahun pada Suku Bajo pada umumnya hanya tinggal di rumah bersama ibunya, yang sepanjang hari kebanyakan bermain di tanggul dan mandi di pinggir laut sambil menunggui orang tuanya kembali dari melaut. Anakanak Suku Bajo pada umunya pandai berenang sejak umur lima tahun sehingga anak laki-laki dapat membantu mengangkat ikan dari perahu atau kapal ke darat atau ke tanggul, sambil mengumpulkan hasil mabbebenya (memperkenankan anak-anak mengambil ikan para nelayan Bajo beberapa ekor sebagai sumber penghasilan, baik untuk dikonsumsi ataupun dijual sebagai uang jajan. untuk dikonsumsi atau dijual). (wawancara, 27/1/2013).

Orang tua Bajo tidak mempunyai berbagai tuntutan yang harus dilakukan secara informal 
oleh anak-anaknya, seperti menghafal surah-surah pendek Alquran, menghafal doa-doa yang berkaitan dengan kehidupan sehari-hari atau menyampaikan kisah-kisah kenabian dan sejarah perjuangan para sahabat Nabi atau pembela tanah air. Hal tersebut terjadi karena, para ibu tidak mempunyai wawasan seperti itu dan pada umumnya kaum ibu tidak tamat SD sehingga pengetahuan dan pengalamannya sangat terbatas untuk memberikan pembinaan secara memadai. Orang tua Bajo lebih membiarkan anaknya tumbuh dan berkembang sendiri menurut alamnya, tanpa mencampuri dan menuntut berbagai kewajiban. Dengan demikian pelaksanaan pendidikan Islam secara informal bagi orang tua Bajo lebih cenderung ke aliran naturalisme yang berpandangan bahwa semua anak dilahirkan berpembawaan baik, dan anak akan menjadi rusak karena pengaruh lingkungan. Pendidikan yang diberikan oleh orang dewasa dapat merusak pembawaan anak yang baik, sehingga pendidikan atau bimbingan dari orang dewasa tidak dapat dipaksakan, dan pendidik harus membiarkan pertumbuhan anak pada alam (Uyoh Sadullah dkk, 2010: 65).

Anak laki-laki dilibatkan melaut menemani bapaknya mencari rezeki, sehingga waktunya lebih banyak di atas air daripada di darat atau lebih dominan di dalam perahu daripada di rumah. Oleh karena itu, belajar secara informal yang banyak mereka dapatkan di laut (di atas perahu).

Pendidikan Islam di rumah atau diperahu tidak permanen karena kurang mendapat perhatian orang tua, disebabkan tidak punya kemampuan membimbing dan mendidik. Dengan demikian penanaman dan pewarisan nilai-nilai dan pengetahuan melaut secara praktis dan langsung dilakukan di atas laut.

\section{Partisipasi Suku Bajo di Kabupaten Bone secara Formal terhadap Pendidikan Islam \\ Pendidikan anak usia dini (Paud) pada suku Bajo}

Lembaga pembinaan usia dini pada umumnya di Kelurahan Bajoe dekat dari pemukiman Bajo, bahkan empat diantaranya terletak di kampung Bajo yaitu: Kelompok Bermain Bahari di jalan Cekalang, TK PADU Manurungge dan RA/TPA di Jalan Tanggul sebelah timur perkampungan Bajo, RA Amir al-Jannah di Jalan Yos Sudarso Lingkungan Apasareng, dan RA Nur al-Huda di Jalan Yos Sudarso. Dua di antaranya didirikan di Lingkungan Bajo yaitu Kelompok Bermain Bahari dan TK PADU Manurungge, sehingga angka partisipasi mencapai 91\% yaitu 67 anak dari sejumlah 75 orang, yang selebihnya 9\% dengan alasan belum siap antar jemput dari rumah ke lokasi PAUD.

Animo orang tua Bajo terhadap pendidikan anak usia dini mulai tumbuh pada tiga tahun terakhir, hal tersebut dipicu oleh beberapa faktor yaitu: lokasi pembinaan PAUD dibangun di lingkungan Bajo; adanya proaktif dari pengasuh, tutor atau pembina untuk mengajak orang tua Bajo memasukkan anaknya di lembaga pembinaan PAUD; anak usia di bawah sepuluh tahun belum mampu membantu orang tua mencari rezeki di laut; PAUD diselenggarakan secara gratis sehingga cukup merangsang orang tua Bajo untuk mengawasi dan memotivasi anaknya untuk ikut serta.

\section{Pendidikan suku Bajo di madrasah ibtidaiyah}

Di kelurahan Bajoe terdapat tujuh SD yaitu: a) SD N0. 18 b) SD Inpres 3/77 dan c) SD Inpres 4/82 ketiganya terletak di Lingkungan Rompe. d) SD Inpres 3/77 di Lingkungan Pao, e) SD Inpres 5/81, f) SD Inpres 10/73 dan g) SD 17. Ketiganya sekolah tersebut terletak di Lingkungan Appasareng, dan hanya ada satu Madrasah Ibtidaiyah yang terletak di Lingkungan Bajo. Anak-anak Suku Bajo hanya tertarik dan mendominasi MIS Bajoe tiga tahun terakhir dari 167 siswa, terdiri 133 siswa dari Suku Bajo (80\%), selebihnya: 34 siswa dari Suku Bugis (20\%). karena MIS satu-satunya madrasah yang sangat dekat dengan perkampungan Suku Bajo. Demikian juga yang tamat tiga tahun terakhir mencapai 75\% dari siswa Suku Bajo. Selama tiga tahun (2010-2013) ada 59 anak-anak suku Bajo yang tamat di MIS, namun yang lanjut ke MTs hanya 9 orang, yang melanjutkan ke MA hanya 6 orang, itupun pada umumnya tidak tamat, belum ada yang sarjana karena seringnya ikut mencari rezeki di laut.

Menurut Hj. ST. Narwiah (Kepala MIS Bajoe) bahwa tertariknya Suku Bajo dalam menyekolahkan anaknya di MIS belakangan ini adalah dipicu: 1) Adanya proaktif dari guru. 2) MIS berada di dekat perkampungan Bajo. 3) Adanya dana gratis, dana BOS serta dana lainnya yang cukup merangsang orang tua Bajo dalam mengikutkan dan mengawasi anak-anaknya dalam bersekolah (Wawancara, 17/1/2013).

Dewasa ini animo orang tua Bajo untuk menyekolahkan anaknya di MIS mulai tumbuh, demikian juga pendidikan keagamaan dalam rumah tangga khususnya mengaji mulai menjadi perhatian mereka, yang dilakukan di sore hari sesudah salat Asar dan di malam hari sesudah salat Magrib setiap 
hari atau setiap malam kecuali hari/malam minggu. Guru mengaji tersedia di dalam perkampungan suku Bajo seperti yang diasuh oleh Manniaga, Yasirah, Hj. Dg. Nitirrang dan H. Sarkawi, dengan menggunakan metode Bugdadiyah sementara di Mesjid Amir Ilham dan Mesjid Azzaharatuddin menggunakan metode iqra'.

Menurut data sensus Kelurahan Bajoe jumlah anak usia SD pada suku Bajo di Kab. Bone tahun 2013 cukup potensial yaitu: 80 orang, walaupun yang terdaftar hanya 50 orang $=62,5 \%$, yang terdiri dari 18 laki-laki dan 32 orang perempuan. Sekitar 30 orang $=37,5 \%$ yang belum sekolah yang pada umumnya bekerja membantu orang tua mencari rezeki di laut.

Berhenti sebelum tamat menurut $\mathrm{Hj}$. ST Narwiah (Kepala MIS Bajoe) menjadi kebiasaan anak-anak Suku Bajo sekian lama, yang dipentingkan adalah mampu membaca, menulis dan berhitung sudah cukup baginya, karena mereka tidak berharap lebih dari itu, di samping alasan tidak punya biaya, juga desakan orang tua agar anakanak segera meringankan beban mencari rezeki untuk memenuhi kebutuhan pokoknya. Setelah digulirkannya pendidikan gratis dan hadirnya dana BOS Suku Bajo mulai terangsang, sehingga droup out menurun secara drastis. Pada Tahun ajaran 2008/2009 jumlah anak-anak Suku Bajo di MIs kelas III sebanyak 22 orang, tamat 17 orang, droup out 5 orang. Pada tahun Ajaran 2009/2010 jumlah anak Suku Bajo kelas III sebanyak 22 orng, tamat 16 orang dan DO 6 orang, dan tahun ajaran 2010/2011 jumlah kelas III sebanyak 25 orang, tamat 19 orang dan DO 6 orang (wawancara, 17/1/2013).

Setiap tahun selalu ada yang droup out namun kelihatan menurun dari tahun ke tahun. Dan yang droup out pada umumya laki-laki karena ikut membantu orang tuanya mencari kayu bakar atau mencari ikan di laut. Pendidikan formal yang diminati oleh anak-anak Suku Bajo lebih memilih MIS, daripada SD karena MIS lebih dekat pada kampung Bajo.

\section{Pendidikan suku Bajo di madrasah tsanawiyah}

Kondisi dan fasilitas lembaga pendidikan formal tingkat SLTP cukup tersedia dan tidak begitu jauh dari perkampungan Bajo. SMPN 7 Bajoe, MTs al-Nurain Lonrae, dan MTs al-Amir fi al-Jannah masing-masing berjarak satu kilometer dari perkampungan Bajo. Jumlah usia SLTP pada anak Suku Bajo adalah 191 orang, namun yang sekolah sebanyak 54 orang $=28,3 \%$, dengan rincian
4 orang di MTs Al-Nurain, 38 orang di MTs Amir Fil-Jannah dan 12 orang di SMPN 7 Bajoe. Tidak sekolah sebanyak 137 orang=71,7\%. Anak-anak Suku Bajo pada usia SLTP lebih cenderung ke MTs karena lebih dekat (Bandingkan dengan Nurul Wakiah, 2008: 40).

\section{Pendidikan suku Bajo di madrasah aliyah}

Kondisi dan fasilitas lembaga pendidikan formal tingkat SLTA tidak begitu jauh, karena hanya sekitar enam ratus meter dari perkampungan Bajo ke arah Barat terdapat Madrasah Aliyah al-Amir fi al-Jannah satu lokasi dengan Madrasah Tsanawiyah al-Amir fi al-Jannah yang terletak di Jalan Kesehatan Lingkungan Appasareng, kemudian jarak satu kilometer dari perkampungan Bajo terdapat SMK Pelayaran Baruna Jaya yang terletak di Jalan Yos Sudarso, selanjutnya Balai Latihan Kerja (BLK) hanya sekitar dua kilometer dari perkampungan Bajo, sekitar dua kilometer kearah utara terdapat SMA 6 Bajoe dan sekitar lima kilometer ke Ibukota Watampone terdapat Madrasah Aliyah II yang terletak poros jalanan Yos Sudarso dapat dijangkau dengan naik sepeda, becak, ojek dan mobil angkutan umum. Sepertinya tidak ada hambatan bagi Suku Bajo untuk tidak berpartisipasi dalam kegiatan pendidikan formal, kecuali alasan mitos dan tradisional yang menjadi pertanda tentang lemahnya aspirasi orang tua terhadap pendidikan dan rendahnya animo anak-anak Suku Bajo mengenai belajar. Dari 68 orang peserta didik MA al-Amir fi al-Jannah hanya 6 orang di antaranya Suku Bajo 3 orang dikelas I dan 3 orang di kelas III, padahal yang tamat di Madrasah Tsanawiyah Amir fi al-Jannah selama tiga tahun terakhir adalah sebanyak 9 orang. Demikian juga, di MAN II Watampone dengan jumlah peserta didik 360 orang 11 di antaranya anak-anak Suku Bajo, SMA 5 Bajoe dengan jumlah peserta didik 662 orang hanya 17 orang Suku Bajo=2,56\%. Jumlah usia SMA/MA pada Suku Bajo adalah 196 orang, namun yang memberikan partisipasinya sebanyak 34 orang, yang tidak sekolah 162 orang karena menjadi tulang punggung keluarga dalam mencari rezeki di laut (Bandingkan dengan Syamsul Bahri, 2010: 93).

\section{Pendidikan suku Bajo pada perguruan tinggi agama Islam}

Ada berbagai perguruan tinggi di Kota Watampone, yang masing-masing mempunyai spesifikasi tersendiri: 1) Universitas Negeri Makassar, 2) Sekolah Tinggi Ilmu Hukum (STIH) 
Pengayoman, 3) Sekolah Tinggi Ilmu Ekonomi (STIE) YAPI, 4) Sekolah Tinggi Ilmu Administrasi (STIA) dan Sekolah Tinggi Ilmu Kesehatan (STIKES) Puang Rimaggalatung, 5) Sekolah Tinggi Keguruan dan Ilmu Pendidikan (STKIP) Muhammadiyah, 6) Akademi Keperawatan (AKPER) dan Akademi Kebidanan (AKBID) Bataritoja, 7) Akademi Keperawatan (AKPER) dan Akademi Kebidanan (AKBID) Lapatau Matannatikka, 8) Sekolah Tinggi Agama Islam (STAI) al-Gazali Bone, 9) Sekolah Tinggi Agama Islam Negeri (STAIN).

Dari kesembilan perguruan tinggi tersebut hanya STAI al-Gazali dan STAIN Watampone yang tergolong perguruan tinggi Agama. STAI al-Gazali Bone mempunyai program studi Pendidikan Agama Islam dan Pendidikan Guru Raudah al-Atfal, sedangkan STAIN Watampone mempunyai Jurusan Tarbiyah dengan program studi Pendidikan Agama Islam, Pendidikan Bahasa Arab, Pendidikan Bahasa Inggris dan Manajemen Pendidikan Islam. Hanya ada satu orang Suku Bajo yang pernah kuliah di STAI al-Gazali tetapi setelah semester satu berhenti, demikian juga di STAIN Watampone baru satu orang Suku Bajo yang kuliah sementara di semester enam program studi Pendidikan Agama Islam (PAI). Belum ada Suku Bajo yang sarjana, baru tiga orang tamatan SMA, tiga orang tamatan MTs, 15 orang tamatan MIS, sehingga belum tercerahkan.

\section{Pendidikan Islam secara non-formal pada suku Bajo di kabupaten Bone}

Perhatian Suku Bajo terhadap pendidikan non formal terutama pendidikan Islam baru bertumpu pada pengajian Alquran karena hadirnya mesjid Amirul Ilham di perkampungan Bajo pada Jalan Cakalang dan mesjid Azzahratuddin di bagian selatan tanggul Jalan $\mathrm{H}$. Tonggo yang menyelenggarakan TPA dengan sistim iqra' dan sistim bagdadiyah yang diselenggaran oleh orang tua Bajo, sehingga anak-anak Suku Bajo secara pelan dapat membaca Alquran secara tartil.

Majelis taklim mulai terlaksana di Kampung Bajo setelah terbangunnya Mesjid Azzahratuddin dan Mesjid Amir Ilham hanya saja masih terbatasnya nara sumber yang dapat memberikan pengajian secara rutin, sehingga Suku Bajo hanya mendapat siraman rohani pada setiap hari Jumat, majelis taklim sekali sebulan dan ceramah Ramadan setiap tahun yang dibina oleh pesantren al-Amir fi al-Jannah. Demikian pula mengenai remaja mesjid anak-anak Suku Bajo belum mampu memberikan partisipasinya secara riil karena mereka belum punya keterampilan dan pengalaman untuk melakukan tugas itu, bahkan mereka masih tampak sangat minder dalam bergaul. Untuk sementara waktu pengurus mesjid Amir Ilham masih didominasi oleh orang Bugis.

Problema pendidikan Islam secara non formal bagi Suku Bajo adalah belum adanya wadah atau organisasi yang dapat menggiring Suku Bajo dan generasinya dalam meningkatkan wawasan pengetahuan agama Islam serta tidak adanya orang tua yang mempunyai pengetahuan yang memadai tentang agama Islam terutama dari golongan Lolo Bajo yang selalu diikuti sepak terjangnya dan didengar nasehatnya.

\section{PENUTUP}

Gambaran pola dan orientasi hidup di laut pada Suku Bajo di Kabupaten Bone, dalam artian lahir, hidup dan terkadang matinya di laut, karena laut adalah lumbung makanan, obat, lalulintas, tempat menguatkan badan, tempat tinggal, sahabat dan tempat bersemayam roh nenek moyangnya. Satu-satunya sumber rezeki hanya di laut dengan pola pencarian yang dinamakan pallibu, papongka, sakai dan lame dengan menggunakan perahu, perahu motor, kapal sehingga terkenallah Suku Bajo sebagai pengelana laut yang unggul/ulung, sea nomaden, sea gypsies, mempunyai budaya maritim atau aqua culture.

Persepsi Suku Bajo tentang pendidikan Islam, dapat dilihat dalam bentuk sikap, motivasi, minat, pengetahuan dan pengalaman, kepentingan dan harapan yang masih negatif, rendah dan kurang perhatian, karena sekolah bagi mereka merupakan gangguan yang menyita waktunya untuk mencari ikan di laut, pendidikan tidak dijadikan sebagai sarana untuk meningkatkan harkat dan martabat, bahkan merasa bahwa pendidikan bukan diperuntukkan bagi suku Bajo sehingga kurang diminati dan belum tertarik karena alasan ekonomi dan persepsi yang masih kabur.

Tingkat partisipasi suku Bajo terhadap pendidikan Islam sangat rendah karena budaya yang berkonsentrasi di laut, anak usia lima belas tahun ke atas diikutkan ke laut, masih kurangnya sosialisasi tentang pentingnya IPTEKS, lamban dalam berbaur, sebagian masih miskin dan belum ada kesadaran untuk berubah.

\section{UCAPAN TERIMA KASIH}

Ucapan terima kasih disampaikan kepada pengelola Jurnal Al-Qalam atas kesediaannya 
memuat tulisan saya. Ucapan yang sama juga disampaikan kepada teman-teman dosen STAIN Watampone yang telah memberikan subangsih demi terselesaikannya tulisan ini.

\section{DAFTAR PUSTAKA}

Abdullah K. "Suku Bajo di Kabupaten Bone dan Pola Penghidupannya" Penelitian Individual Fakultas Syariah IAIN Alauddin Watampone, 1990.

------. "Persepsi Orang Tua mengenai Belajar dan Pengaruhnya terhadap Program Wajar Dikdas 9 Tahun (Studi Kasus pada Suku Bajo di Kabupaten Bone Sulawesi Selatan". Laporan Hasil Penelitian Individual Watampone: STAIN Watampone, 2000.

-------. 2013 Suku Bajo di Kabupaten Bone (AsalMuasal dan Pola Hidup di Laut), Cet. I Watampone: Lukman Al-Hakim Press.

Bahri, Syamsul. 2010 "Adaptasi Sosial Komunitas Bajo (Proses Belajar Kolektif dan Inklusivitas Sosial dalam Interaksi dengan Masyarakat Bugis di Bone Sulawesi Selatan)". Disertasi, Program Pascasarjana Universitas Makassar,

Mubyarto, Loekman Sutrisno dan Michael Dove. 1984. Nelayan dan Kemiskinan Studi Antropologi di Dua Desa Pantai. Jakarta: PT. Rajawali.
Muharram, Laode. 1993. Pola Hidup dan Sikap Mental Nelayan Bajo di Sulawesi Tenggara. Kendari: Universitas Haluoleo.

Musdalipa. 1998. "Peranan Komunikasi Sosial Dalam Peningkatan Etos Kerja Masyarakat Bajo Desa Bajoe Kabupaten Bone". Skripsi, Sarjana S1 Fakultas Dakwah IAIN Alauddin Ujung Pandang.

Saad, Sudirman. 2009. Bajo Berumah di Laut Nusantara. Jakarta: t.p.

Sadullah, Uyoh dkk. 2010. Pedagogik (Ilmu Mendidik), Cet. I, Bandung: Alfabeta.

Sawe, Dahlan dkk. 1985. "Profil Masyarakat Bajo Desa Bajoe Kabupaten Bone". Laporan Penelitian Universitas Hasanuddin Ujung Pandang.

Soesangobing, Herman. 1977. "Perkampungan Bajo di Bajoe'. Laporan Hasil Penelitian, Pemda TK. II Bone.

Wakia, Nurul. 2008. "Apresiasi Orang Tua terhadap Eksistensi Lembaga Pendidikan Islam Tingkat Lanjutan (Studi Kasus Respon Masyarakat Suku Bajo Terhadap Eksistensi MTs dan MAN)". Skripsi, S1 Jurusan Tarbiyah STAIN Watampone.

Yamin, Muhammad. 1996. "Adaptasi Suku Bangsa Bajo dengan Masyarakat Sekitarnya Di Desa Bajoe Kabupaten Bone". Skripsi Sarjana S1, FPIPS IKIP: Ujung Pandang. 